\title{
Isotopically enriched ammonium shows high nitrogen transformation in the pile top zone of dairy manure compost
}

\author{
Koki Maeda ${ }^{1,2}$, Sakae Toyoda ${ }^{2}$, Midori Yano ${ }^{2, a}$, Shohei Hattori ${ }^{3}$, Makoto Fukasawa ${ }^{2}$, Keiichi Nakajima ${ }^{1}$, and \\ Naohiro Yoshida ${ }^{3,4}$ \\ ${ }^{1}$ NARO, Hokkaido Agricultural Research Center, Dairy Research Division, 1 Hitsujigaoka, Sapporo 062-8555, Japan \\ ${ }^{2}$ Department of Environmental Science and Technology, Tokyo Institute of Technology, 4259 Nagatsuta, \\ Midori-ku, Yokohama 226-8502, Japan \\ ${ }^{3}$ Department of Environmental Chemistry and Engineering, Tokyo Institute of Technology, 4259 Nagatsuta, \\ Midori-ku, Yokohama 226-8502, Japan \\ ${ }^{4}$ Earth-Life Science Institute, Tokyo Institute of Technology, 2-12-1 Ookayama, Meguro-ku, Tokyo 152-8550, Japan \\ ${ }^{a}$ now at: Center for Ecological Research, Kyoto University, 509-3, 2-chome, Hirano, Otsu, Shiga 520-2113, Japan
}

Correspondence to: Koki Maeda (k_maeda@affrc.go.jp)

Received: 13 April 2015 - Published in Biogeosciences Discuss.: 20 May 2015

Revised: 8 February 2016 - Accepted: 14 February 2016 - Published: 2 March 2016

\begin{abstract}
Nitrogen isotope ratios $\left(\delta^{15} \mathrm{~N}\right)$ of $\mathrm{NH}_{4}^{+}$in dairy manure compost piles with and without bulking agent $(10 \% w / w)$ were compared to understand the effects of the use of bulking agent on nitrogen conversion during manure composting. The $\delta^{15} \mathrm{~N}-\mathrm{NH}_{4}^{+}$values in each of three pile zones (top, side and core) were also compared. At the end of the process, piles with bulking agent showed significantly higher $\delta^{15} \mathrm{~N}$ values $(17.7 \pm 1.3 \%$ ) than piles without bulking agent $(11.8 \pm 0.9 \%$ ), reflecting the significantly higher nitrogen conversion and $\mathrm{NH}_{3}$ loss in the former. The samples from the top zone, especially in the piles with bulking agent, showed very high $\mathrm{NH}_{4}^{+}$concentrations with significantly high ${ }^{15} \mathrm{~N}\left(\delta^{15} \mathrm{~N}: 12.7-29.8 \% o\right)$ values, indicating that extremely high nitrogen conversion, nitrificationdenitrification activity of the microbes and $\mathrm{NH}_{3}$ volatilization occurred in this zone.
\end{abstract}

\section{Introduction}

Nitrogen is one of the most abundant major elements in the Earth's atmosphere. There are two major anthropogenic activities affecting the global nitrogen cycle: energy production and food production (Galloway et al., 2004). Because nitrogen is one of the most important elements for plant nutrition, huge amounts of industrially fixed nitrogen are used as fertil- izer to improve the productivity of agricultural crops (Tilman et al., 2002). Current anthropogenic nitrogen input to the environment $\left(160 \mathrm{Tg} \mathrm{year}^{-1}\right)$ is already greater than the input from natural biological fixation $(110 \mathrm{Tg})$ on land or in the ocean (140 Tg) (Gruber and Galloway, 2008), and the significance of agricultural nitrogen input on the global nitrogen cycle is expected to increase along with the nutritional needs of a growing population. In the livestock production industry, livestock intake organic nitrogen from their feed, and produce large quantities of organic nitrogen in the form of manure, a byproduct and potential resource which must be handled appropriately to protect the environment (Sharpley et al., 1998). Most of this manure is used as organic fertilizer for efficient nutrient cycling, and thus a proper understanding of nitrogen flow in the manure management system is critically important.

The nitrogen contained in dairy manure exists mostly as organic nitrogen or $\mathrm{NH}_{4}^{+}$. Through the composting process, the heat production by degradation of organic matter leads to a significant loss of nitrogen into the atmosphere as gaseous ammonia $\left(\mathrm{NH}_{3}\right)$ (Dämmgen and Hutchings, 2008). Nitrifiers and other families of microorganisms in the manure also convert this nitrogen as nitrite $\left(\mathrm{NO}_{2}^{-}\right)$or nitrate $\left(\mathrm{NO}_{3}^{-}\right)$, and both nitrifiers and denitrifiers can use them as electron acceptors. They reduce these nitrogen oxides into dinitrogen $\left(\mathrm{N}_{2}\right)$ and return them to the atmosphere in a process called denitrifica- 
tion (Zumft, 1997). Nitrous oxide $\left(\mathrm{N}_{2} \mathrm{O}\right)$, a greenhouse gas, is emitted through the nitrogen conversion in the composting process (Sommer et al., 2009). Because it is known that $\mathrm{N}_{2} \mathrm{O}$ has very strong greenhouse effects (298-fold greater than the greenhouse effects of $\mathrm{CO}_{2}$ over a 100 -year time horizon; IPCC, 2007), and $\mathrm{N}_{2} \mathrm{O}$ is also known to contribute to ozone layer destruction (Ravishankara et al., 2009), these gas emissions must be mitigated.

With respect to this $\mathrm{N}_{2} \mathrm{O}$ emission, our previous studies clarified that nitrification occurs in the compost surface, and compost turning (mixing by machines) and subsequent denitrification can be major sources of $\mathrm{N}_{2} \mathrm{O}$ (Maeda et al., 2010b, 2013b). Also, we have shown that the appropriate use of bulking agents can reduce the $\mathrm{N}_{2} \mathrm{O}$ emission significantly (Maeda et al., 2013a). However, the mechanism of this $\mathrm{N}_{2} \mathrm{O}$ mitigation is largely unknown. Because bulking agents are generally used to increase the supply of oxygen to the compost piles (Jolanun and Towprayoon, 2010), it is expected that the increase in oxygen increases nitrification and the subsequent $\mathrm{N}_{2} \mathrm{O}$ production.

To solve this contradiction, we compared the level of $\delta^{15} \mathrm{~N}-\mathrm{NH}_{4}^{+}$in these composts, because this parameter can be used to track the level of reaction involving $\mathrm{NH}_{4}^{+}$in the environment (Brooks et al., 1989; Garten Jr., 1992; Yeatman et al., 2001). Because it has already been established that the $\mathrm{NO}_{x}^{-}$accumulation and the bacterial communities are different in different regions of the pile (Maeda et al., 2010a), we sampled from both the compost side and core independently, and surveyed them into the $\delta^{15} \mathrm{~N}-\mathrm{NH}_{4}^{+}$analysis.

\section{Materials and methods}

\subsection{Composting experiment}

The composting experiment was performed three times at the Hokkaido Agricultural Research Center (Sapporo City, Hokkaido): once from 27 May through 21 July in 2010 (run 1), once from 15 September through 10 November in 2010 (run 2) and once from 19 May through 14 July in 2011 (run 3). The cows were fed orchard grass silage and corn silage, oat hay, alfalfa hay, beet pulp and two types of concentrate mixtures to meet their digestible energy requirements, as recommended by the Japanese Feeding Standard for dairy cattle. Lactating Holstein cow excrement and dried grass (Orchard grass; Dactylis glomerata) were used in this study to make the compost.

About $4000 \mathrm{~kg}$ of dairy cow excrement and $400 \mathrm{~kg}$ of dried grass were mixed to form the treatment pile (pile 1), while the control pile (pile 2) consisted of dairy cow excrement alone. The compost was piled up on a waterproof concrete floor, and turned once every 2 weeks with a front loader and manure spreader. Each pile had a volume of $7.5 \mathrm{~m}^{3}$ with pile dimensions of $4 \mathrm{~m}$ in diameter and $1.8 \mathrm{~m}$ in height at the start of the experiment. The temperatures of the compost piles and the ambient air were measured hourly using a Thermo Recorder RTW-30S (Espec, Japan).

\subsection{Chemical analysis of the compost}

Fresh samples (about $1 \mathrm{~kg}$ ) were taken from each of three zones (the pile top, side, and core) just before each turning. Samples were also taken just after each turning, at the start and the end of the three composting experiments. Details of the sampling are described in Fig. S1 in the Supplement. Samples were homogenized and fresh subsamples were used to measure total solids, volatile solids, inorganic $\mathrm{N}, \mathrm{pH}$ and electrical conductivity, or stored at $-20^{\circ} \mathrm{C}$ for total nitrogen determination. Total solids (TS) were measured after drying the samples overnight at $105^{\circ} \mathrm{C}$, and dried samples were powdered and used for $\mathrm{C} / \mathrm{N}$ ratio determination. Volatile solids (VS) were measured after the samples were processed at $600^{\circ} \mathrm{C}$ for $1 \mathrm{~h}$. Total $\mathrm{N}$ was measured using raw samples by the Kjeldahl method. The $\mathrm{C} / \mathrm{N}$ ratio was determined using a $\mathrm{C} / \mathrm{N}$ analyzer (vario MAX CNS; Elementar, Germany).

To measure inorganic $\mathrm{N}, \mathrm{pH}$ and electrical conductivity, $5 \mathrm{~g}$ of fresh compost was placed into a $50 \mathrm{~mL}$ polypropylene tube with $40 \mathrm{~mL}$ of deionized water, then shaken $(200 \mathrm{rpm}$, $30 \mathrm{~min})$ and centrifuged $(3000 \mathrm{~g}, 20 \mathrm{~min})$. The supernatant was collected and $\mathrm{NH}_{4}^{+}, \mathrm{NO}_{2}^{-}-\mathrm{N}$ and $\mathrm{NO}_{3}^{-}-\mathrm{N}$ were measured using ion chromatography (ICS-1600; Dionex, USA); $\mathrm{pH}$ and electrical conductivity (EC) were determined with calibrated electrodes (Horiba, Japan).

\subsection{Determination of $\delta^{15} \mathrm{~N}-\mathrm{NH}_{4}^{+}$levels and Rayleigh plot analysis}

The amount of $\delta^{15} \mathrm{~N}-\mathrm{NH}_{4}^{+}$in the extracted samples or trapped $\mathrm{NH}_{3}$ samples was determined by the diffusion method (Holmes et al., 1998).

One-centimeter diameter GF/D filters (Whatman, UK) were cut into four pieces, acidified with $20 \mu \mathrm{L} \mathrm{H}_{3} \mathrm{PO}_{4}$ $(0.02 \mathrm{mM})$ and sandwiched between $2.5 \mathrm{~cm}$, diameter $10 \mathrm{~mm}$ pore-size Teflon membranes (Millipore, USA). These filter packs were used as an ammonium trap in the samples. Ten milliliters of the $\mathrm{NH}_{4}^{+}-\mathrm{N}$ samples $(50 \mu \mathrm{g} \mathrm{N})$ was placed in $15 \mathrm{~mL}$ tubes and $0.5 \mathrm{~g}$ of $\mathrm{NaCl}$ (ashed at $450^{\circ} \mathrm{C}$ for $8 \mathrm{~h}$ ) was added. Then a single filter pack was added to the $15 \mathrm{~mL}$ tube, and $0.03 \mathrm{~g} \mathrm{MgO}$ (ashed at $450^{\circ} \mathrm{C}$ for $8 \mathrm{~h}$ ) was added to convert $\mathrm{NH}_{4}^{+}$in the samples into $\mathrm{NH}_{3}$. The $15 \mathrm{~mL}$ tubes were incubated at $40^{\circ} \mathrm{C}$ for 2 weeks with stirring at $200 \mathrm{rpm}$. After incubation, the filter pack was removed from the tubes and dried in a desiccator for 2 days. The dried filter was then recovered and placed in a tin cup. The tin cup containing the filter was then analyzed by an elemental analyzer (EA1110, CE Instruments, Ltd., Wigan, UK) coupled with an isotope ratio mass spectrometer (MAT252; ThermoFisher Scientific $\mathrm{KK}$, Yokohama, Japan) to quantify $\delta^{15} \mathrm{~N}_{-} \mathrm{NH}_{4}^{+}$in the samples. Calibration was conducted with IAEA-N1 and IAEA- 
$\mathrm{N}_{2}\left(\mathrm{NH}_{4} \mathrm{SO}_{4}\right)$, and the precision $(1 \sigma)$ was better than $0.2 \%$. The $\delta^{15} \mathrm{~N}$ of samples was expressed in parts per thousand deviations from the atmospheric $\mathrm{N}_{2}$ as defined by the following equation:

$\delta^{15} \mathrm{~N}(\% \circ)=\left(\left(R_{\text {sample }} / R_{\text {standard }}\right)-1\right) \times 1000$,

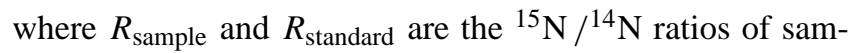
ples and the atmospheric $\mathrm{N}_{2}$, respectively. Isotopic fractionation factor $\alpha$ was expressed as

$\alpha=\frac{R_{\mathrm{B}}}{R_{\mathrm{A}}}$,

where $R_{\mathrm{A}}$ and $R_{\mathrm{B}}$ are the isotopic ratio of phase $\mathrm{A}$ and $\mathrm{B}$, respectively.

Isotopic fractionation can also be described by the enrichment factor $\varepsilon$, which describes the enrichment of the product relative to that of the substrate, and which is also expressed in per mill $(\%)$.

$\varepsilon=(\alpha-1) \times 1000$

The evolution of the isotopic composition is described by a Rayleigh equation with a fractionation factor as follows for ${ }^{15} \mathrm{~N}$ :

$R / R_{0}=\frac{\left(1+10^{-3} \delta^{15} \mathrm{~N}\right)}{\left(1+10^{-3} \delta^{15} \mathrm{~N}_{0}\right)}=\left(\frac{\left[\mathrm{NH}_{4}^{+}\right]}{\left[\mathrm{NH}_{4}^{+}\right]_{0}}\right)^{\alpha-1}$,

where $R$ and $R_{0}$ are the isotope ratio of samples just before the turning and of the samples just after the previous turning, respectively. Since the piles were homogenized at each turning event, the amount of ammonium in a sample just after the previous turning event was taken as the "initial ammonium". $\delta^{15} \mathrm{~N}$ and $\delta{ }^{15} \mathrm{~N}_{0}$ are the respective $\delta$ values for the each $\mathrm{NH}_{4}^{+}$. $\left[\mathrm{NH}_{4}^{+}\right]_{0}$ and $\left[\mathrm{NH}_{4}^{+}\right]$are the ammonium concentration of the samples just after the previous turning event and the samples just before the subsequent turning event, respectively. Using the approximation of $\ln (1+x) \cong x$ with $x \ll 1$, the relationship between the difference of $\delta^{15} \mathrm{~N}$ values between pile turnings and the reaction rate of the substrate was obtained from Eqs. (3) and (4) as follows:

$\delta^{15} \mathrm{~N}-\delta^{15} \mathrm{~N}_{0}=\varepsilon \ln (1-f)$,

where $f$ is the amount of reacted ammonium between the turning events, defined as $f=\left(1-\frac{\left[\mathrm{NH}_{4}^{+}\right]}{\left[\mathrm{NH}_{4}^{+}\right]_{0}}\right)$.

\subsection{Keeling plot analysis}

The basis of the Keeling plot method is conservation of mass. The ammonium concentration of each location of the pile before the pile turnings can be expressed as

$c_{\mathrm{b}}=c_{\mathrm{a}}+c_{\mathrm{s}}-c_{\mathrm{v}}$, where $c_{\mathrm{b}}, c_{\mathrm{a}}, c_{\mathrm{s}}$, and $c_{\mathrm{v}}$ are the ammonium concentration measured in each location of the pile just before the turning, the ammonium concentration just after the previous pile turning, the additional concentration component produced by the source, and decrease in ammonium concentration caused by volatilization of $\mathrm{NH}_{3}$, respectively. Given conservation of mass, we have

$\delta^{15} \mathrm{~N}_{\mathrm{b}} c_{\mathrm{b}}=\delta^{15} \mathrm{~N}_{\mathrm{a}} c_{\mathrm{a}}+\delta^{15} \mathrm{~N}_{\mathrm{s}} c_{\mathrm{s}}-\delta^{15} \mathrm{~N}_{\mathrm{v}} c_{\mathrm{v}}$,

where $\delta^{15} \mathrm{~N}$ represents the nitrogen isotope ratio of the ammonium in each sample or lost ammonium. Here we assume that $c_{\mathrm{V}}$ is proportional to $c_{\mathrm{b}}$ and that the difference between $\delta^{15} \mathrm{~N}_{\mathrm{v}}$ and $\delta^{15} \mathrm{~N}_{\mathrm{b}}$ is constant,

$c_{\mathrm{v}}=k c_{\mathrm{b}}$

$\delta^{15} \mathrm{~N}_{\mathrm{v}}=\delta^{15} \mathrm{~N}_{\mathrm{b}}+\varepsilon_{\mathrm{v}}$.

Then, Eqs. (6) and (7) are simplified as follows:

$(1+k) c_{\mathrm{b}}=c_{\mathrm{a}}+c_{\mathrm{s}}$,

$\left\{\delta^{15} \mathrm{~N}_{\mathrm{b}}+k\left(\delta^{15} \mathrm{~N}_{\mathrm{b}}+\varepsilon_{\mathrm{v}}\right)\right\} c_{\mathrm{b}}=\delta^{15} \mathrm{~N}_{\mathrm{a}} c_{\mathrm{a}}+\delta^{15} \mathrm{~N}_{\mathrm{s}} c_{\mathrm{s}}$.

By combining Eqs. (10) and (11), we arrive at

$$
\begin{aligned}
\delta^{15} \mathrm{~N}_{\mathrm{b}}= & c_{\mathrm{a}}\left(\delta^{15} \mathrm{~N}_{\mathrm{a}}-\delta^{15} \mathrm{~N}_{\mathrm{s}}\right) /(1+k) \cdot\left(1 / c_{\mathrm{b}}\right) \\
& +\delta^{15} \mathrm{~N}_{\mathrm{s}}-k \varepsilon_{\mathrm{v}} /(1+k) .
\end{aligned}
$$

Thus, $\delta^{15} \mathrm{~N}_{\mathrm{b}}$ and $1 / c_{\mathrm{b}}$ have a linear relationship if a single source of ammonium (s) is added to preexisting ammonium (a) under the assumption described above.

\subsection{Statistical analysis}

The chemical component data were analyzed by ANOVA using the general linear model procedure described by SAS (SAS Institute, 2001). Tukey's multiple range comparison tests were used to separate the means. A value of $P<0.05$ was considered statistically significant.

\section{Results}

\subsection{Composting experiments}

The temperature of the piles with bulking agent $(10 \% \mathrm{w} / \mathrm{w})$ exceeded $60^{\circ} \mathrm{C}$ throughout the entire experiment (Fig. S1), while the piles without bulking agent showed significantly lower temperature (below $50^{\circ} \mathrm{C}$ ). The initial weight was $4543 \pm 137 \mathrm{~kg}$ in the piles with bulking agent and $4136 \pm$ $124 \mathrm{~kg}$ in those without bulking agent, and the final turning these values dropped significantly to $1413 \pm 99$ and $1960 \pm 291 \mathrm{~kg}$, respectively (Table 1). The total solids of the piles with and without bulking agent after the composting process were $43.8 \pm 11.3$ and $23.5 \pm 1.8 \%$, respectively. The $\mathrm{C} / \mathrm{N}$ ratios of the piles with and without bulking agent 
Table 1. Chemical components of compost samples.

\begin{tabular}{|c|c|c|c|c|c|c|c|c|c|c|c|c|c|c|c|c|c|c|c|c|c|}
\hline \multirow{2}{*}{$\frac{\text { Time }}{\text { I }}$} & \multirow{2}{*}{ B.A. } & \multirow{2}{*}{$\begin{array}{r}\text { Run } \\
1\end{array}$} & \multirow{2}{*}{$\begin{array}{r}\begin{array}{r}\text { Weight } \\
(\mathrm{kg})\end{array} \\
4280\end{array}$} & \multicolumn{2}{|c|}{$\begin{array}{l}\text { TS } \\
(\%)\end{array}$} & \multicolumn{2}{|c|}{$\begin{array}{c}\mathrm{VS} \\
(\% \mathrm{TS})\end{array}$} & \multicolumn{2}{|c|}{$\begin{array}{c}\mathrm{EC} \\
\left(\mathrm{mS} \mathrm{cm}^{-1}\right)\end{array}$} & \multicolumn{2}{|c|}{$\mathrm{pH}$} & \multicolumn{2}{|c|}{$\begin{array}{c}\mathrm{NO}_{2}^{-}-\mathrm{N} \\
\left(\mathrm{mg} \mathrm{kg}^{-1} \mathrm{TS}\right)\end{array}$} & \multicolumn{2}{|c|}{$\begin{array}{c}\mathrm{NO}_{3}^{-}-\mathrm{N} \\
\left(\mathrm{mg} \mathrm{kg}^{-1} \mathrm{TS}\right)\end{array}$} & \multicolumn{2}{|c|}{$\begin{array}{c}\mathrm{NH}_{4}^{+}-\mathrm{N} \\
\left(\mathrm{mg} \mathrm{kg}^{-1} \mathrm{TS}\right)\end{array}$} & \multicolumn{2}{|c|}{$\begin{array}{c}\mathrm{TKN} \\
\left(\mathrm{g} \mathrm{N} \mathrm{kg}^{-1} \mathrm{TS}\right)\end{array}$} & \multicolumn{2}{|c|}{$\mathrm{C} / \mathrm{N}$} \\
\hline & & & & 20.5 & $(0.2)$ & 84.7 & (0.3) & 2.6 & 0.0 & 8.4 & (0.1) & 0.0 & 0.0 & 68.9 & (1.8) & 4646.3 & (164.7) & 27.6 & (0.3) & 24.2 & $(0.2)$ \\
\hline I & - & 2 & 4060 & 22.7 & (0.6) & 82.3 & (1.1) & 3.1 & 0.0 & 8.8 & (0.1) & 0.0 & 0.0 & 0.0 & 0.0 & 3497.5 & $(51.0)$ & 24.2 & (0.6) & 22.2 & $(0.2)$ \\
\hline I & - & 3 & 4070 & 17.8 & (0.4) & 82.1 & (0.4) & 2.7 & $(0.1)$ & 8.0 & 0.0 & 0.0 & 0.0 & 0.0 & 0.0 & 7347.8 & (7.6) & 26.2 & $(0.4)$ & 22.0 & $(0.4)$ \\
\hline I & + & 1 & 4700 & 28.3 & (0.1) & 87.0 & (0.3) & 2.9 & 0.0 & 8.3 & (0.1) & 0.0 & 0.0 & 40.1 & (0.9) & 2929.3 & $(34.0)$ & 20.8 & (1.0) & 23.0 & (0.1) \\
\hline I & + & 2 & 4480 & 31.2 & $(0.7)$ & 87.1 & (0.8) & 3.2 & 0.0 & 8.8 & 0.0 & 0.0 & 0.0 & 0.0 & 0.0 & 2288.0 & (10.4) & 21.6 & $(0.7)$ & 27.5 & (1.7) \\
\hline I & + & 3 & 4450 & 22.6 & (0.3) & 86.5 & (0.6) & 3.0 & 0.0 & 7.7 & 0.0 & 0.0 & 0.0 & 0.0 & 0.0 & 5840.3 & (126.1) & 20.4 & (0.4) & 21.0 & (0.3) \\
\hline $\mathrm{F}$ & - & 1 & 1710 & 24.8 & $(0.6)$ & 70.0 & (2.9) & 2.5 & 0.0 & 9.3 & 0.0 & 0.0 & 0.0 & 0.0 & 0.0 & 1353.1 & (75.1) & 32.3 & (1.7) & 13.0 & (0.1) \\
\hline $\mathrm{F}$ & - & 2 & 2280 & 24.3 & $(0.2)$ & 75.1 & (0.4) & 2.6 & $(0.1)$ & 9.5 & $(0.1)$ & 61.2 & (8.6) & 0.0 & 0.0 & 451.1 & $(0.6)$ & 26.7 & (0.6) & 16.3 & 0.0 \\
\hline $\mathrm{F}$ & - & 3 & 1890 & 21.4 & (0.4) & 77.2 & $(0.5)$ & 3.0 & 0.0 & 9.2 & (0.1) & 0.0 & 0.0 & 0.0 & 0.0 & 3817.1 & (177.4) & 28.9 & (1.1) & 17.5 & $(0.2)$ \\
\hline $\mathrm{F}$ & + & 1 & 1190 & 52.7 & (0.9) & 69.1 & (0.6) & 5.0 & (0.1) & 9.5 & 0.0 & 44.3 & (1.6) & 52.6 & $(0.2)$ & 460.9 & (3.3) & 30.0 & 0.0 & 12.0 & (0.1) \\
\hline $\mathrm{F}$ & + & 2 & 1480 & 47.6 & (0.4) & 73.7 & (0.9) & 4.3 & 0.0 & 9.0 & 0.0 & 57.4 & (7.5) & 60.4 & (2.5) & 375.5 & (21.7) & 29.1 & $(0.1)$ & 13.6 & $(0.2)$ \\
\hline $\mathrm{F}$ & + & 3 & 1570 & 31.1 & (1.0) & 71.9 & (1.6) & 4.9 & $(0.1)$ & 9.5 & (0.1) & 53.9 & (6.7) & 49.5 & (12.1) & 1809.8 & (97.8) & 29.2 & $(0.2)$ & 12.7 & 0.0 \\
\hline
\end{tabular}

B.A.: bulking agent; I: initial; F: final; TS: total solids; VS: volatile solids; $\mathrm{EC}$ : electrical conductivity; $\mathrm{NO}_{2}^{-}-\mathrm{N}$ : nitrite-nitrogen; $\mathrm{NO}_{3}^{-}-\mathrm{N}$ : nitrate-nitrogen; $\mathrm{NH}_{4}^{+}-\mathrm{N}$ : ammonium-nitrogen; $\mathrm{TKN}^{-}$total $\mathrm{Kjeldahl}$ nitrogen; $\mathrm{C} / \mathrm{N}$ :
carbon-nitrogen ratio. The values represent the average (standard deviation).
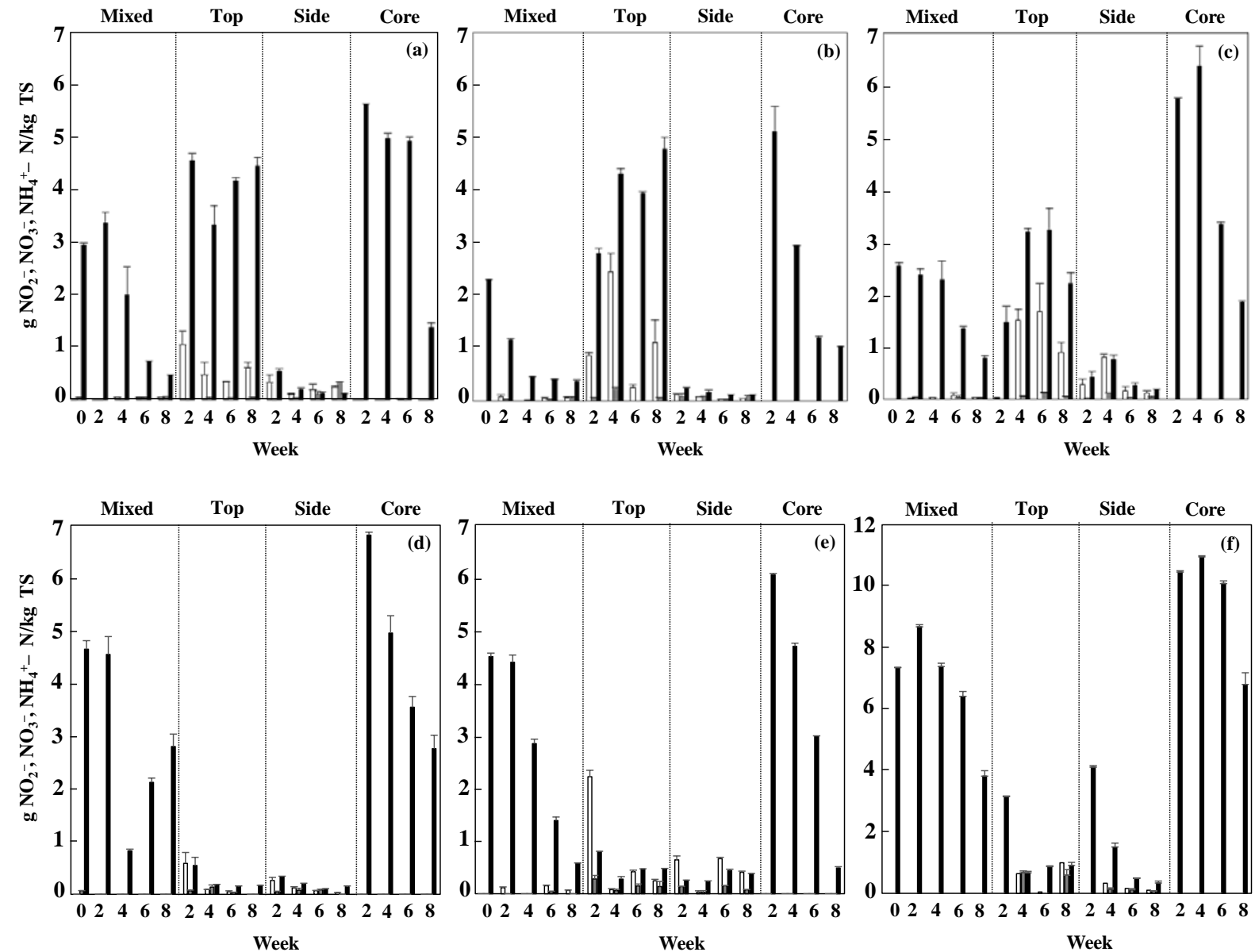

Figure 1. $\mathrm{NO}_{2}^{-}$(white), $\mathrm{NO}_{3}^{-}$(grey) and $\mathrm{NH}_{4}^{+}-\mathrm{N}$ (black) content of the compost samples from each location (top, side and core) of the pile and the sample just after the turnings (mixed). These contents were determined every 2 weeks, just before/after the turning events. (a)(c) indicate the pile 1 of the compost runs $1-3$, and (d)-(f) indicate the pile 2 of the compost runs $1-3$, respectively. The error bars indicate the standard deviation $(n=3)$. 


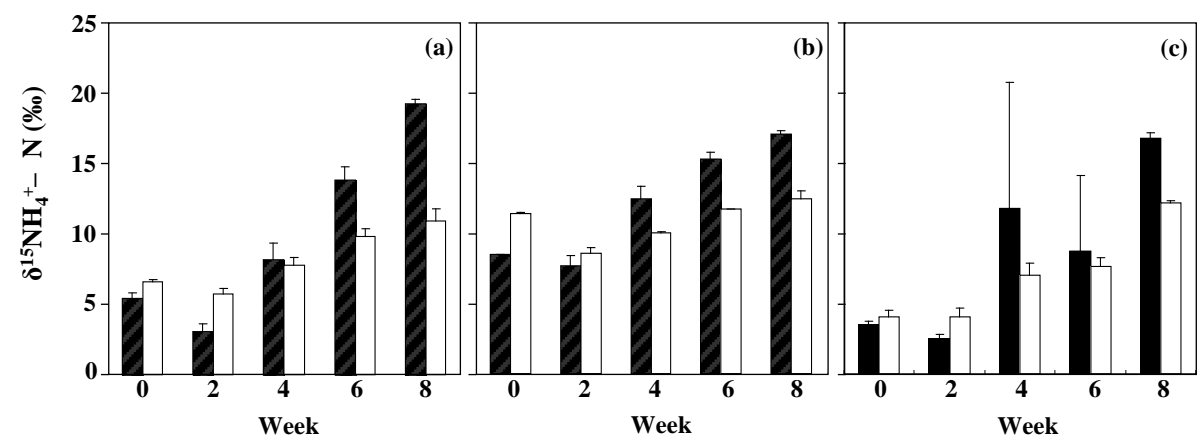

Figure 2. $\delta^{15} \mathrm{~N}$ of $\mathrm{NH}_{4}^{+}$of the mixed samples just after the turning events. The black bars indicate the compost with bulking agent $(10 \% w / w)$ and the white bars indicate the compost without bulking agent. (a)-(c) indicate the compost runs $1-3$. The error bars indicate the standard deviation $(n=2)$.

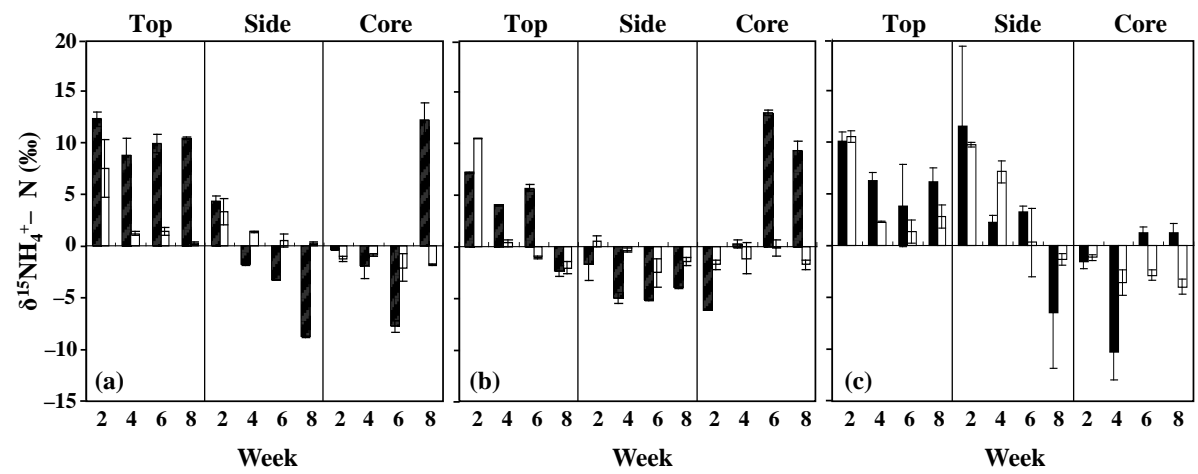

Figure 3. $\delta^{15} \mathrm{~N}$ of $\mathrm{NH}_{4}^{+}-\mathrm{N}$ of the samples from each compost location (pile top, side and core). The values were expressed as the difference from the mixed samples just after the turning events. The black bars indicate the compost with bulking agent $(10 \% w / w)$, and the white bars indicate the compost without bulking agent. (a)-(c) indicate the compost runs $1-3$. The error bars indicate the standard deviation $(n=3)$.

dropped significantly from $23.8 \pm 3.3$ to $12.8 \pm 0.8$ and from $22.8 \pm 1.2$ to $15.6 \pm 2.6$, respectively. These parameters all indicate that the organic matter degradation rate was much higher in the piles with bulking agent.

Pile top samples (2.8-7.4 $\mathrm{mg} \mathrm{N} \mathrm{g}^{-1} \mathrm{TS}$; pile 1) and core samples (1.0-14.6 $\mathrm{mg} \mathrm{N} \mathrm{g}^{-1} \mathrm{TS}$; pile 1) contained higher ammonium concentrations than the pile side samples $(0.1-$ $1.8 \mathrm{mg} \mathrm{Ng}^{-1}$ TS; pile 1) (Fig. 1a-c). High $\mathrm{NO}_{2}^{-}$accumulation was also observed in the pile top samples $(0.03-$ $3.8 \mathrm{mg} \mathrm{N} \mathrm{g}^{-1} \mathrm{TS}$; pile 1), but not in the pile core samples. $\mathrm{NO}_{3}^{-}$was also detected in the pile top and side samples, but the concentrations were low $\left(0-0.29 \mathrm{mg} \mathrm{N} \mathrm{g}^{-1} \mathrm{TS}\right.$; pile 1). Although similar trends were observed for pile 2 (Fig. 1d-f), the amount of $\mathrm{NH}_{4}^{+}$in the top region of pile 2 was generally lower $\left(0.15-2.2 \mathrm{mg} \mathrm{N} \mathrm{g}^{-1} \mathrm{TS}\right)$ than that in pile 1 . Accumulations of $\mathrm{NO}_{2}^{-}\left(0.08-2.2 \mathrm{mg} \mathrm{N} \mathrm{g}^{-1} \mathrm{TS}\right)$ and $\mathrm{NO}_{3}^{-}(0.02-$ $0.7 \mathrm{mg} \mathrm{N} \mathrm{g}^{-1} \mathrm{TS}$ ) were also detected in both the top and side samples of pile 2 .

\section{$3.2 \delta^{15} \mathrm{~N}_{\text {of }} \mathrm{NH}_{4}^{+}$in mixed samples}

$\delta^{15} \mathrm{~N}-\mathrm{NH}_{4}^{+}$values of the mixed samples just after the pile turning events are shown in Fig. 2. All compost runs showed a similar tendency. The initial $\delta^{15} \mathrm{~N}-\mathrm{NH}_{4}^{+}$values were $5.8 \pm$ 2.5 and $7.4 \pm 3.8 \%$ or the piles with and without bulking agent, respectively. These values dropped slightly between weeks 0 and 2, to $4.4 \pm 2.8$ and $6.1 \pm 2.3 \%$ o for piles with and without bulking agent in all runs, although these changes were not statistically significant. After week 4 , these values increased significantly, and at the end of the experiments they reached $17.7 \pm 1.3$ and $11.8 \pm 0.9 \%$ for the piles with and without bulking agent, respectively. Also, the piles with bulking agent showed higher values than the piles without bulking agent, and this difference was statistically significant.

$\delta^{15} \mathrm{~N}-\mathrm{NH}_{4}^{+}$values were also determined for the pile top, side and core samples, and are shown in Fig. 3. The data were expressed as the difference from the mixed samples taken after the pile homogenization. The values for the pile top samples (9.6-22.5\%) were higher than those for the side samples $(9.2-11.3 \%$ ) in both the piles with and without bulking agent. The core samples showed low $\delta^{15} \mathrm{~N}-\mathrm{NH}_{4}^{+}$values in week $2(1.7 \pm 1.0$ and $4.7 \pm 2.0 \%$ o for the piles with and without bulking agent, respectively), reflecting the newly formed "light" $\mathrm{NH}_{4}^{+}-\mathrm{N}$, which was supplied by the degradation of organic $\mathrm{N}$ in the manure. On the other hand, the heaviest $\mathrm{NH}_{4}^{+}(25.4 \pm 6.8 \%$ ) was also observed in the pile core sam- 
ples at the end of the experimental period. This phenomenon was observed only from the piles with bulking agent.

\section{Discussion}

The stable isotope $\delta^{15} \mathrm{~N}$ value of $\mathrm{NH}_{4}^{+}$in dairy manure compost with and without bulking agent was studied to clarify the mechanism of the significant $\mathrm{N}_{2} \mathrm{O}$ mitigation achieved using a bulking agent. A decrease in the $\delta^{15} \mathrm{~N}$ value of $\mathrm{NH}_{4}^{+}$ in the first 2 weeks of composting was observed in both piles, although this result was not observed in the previous study (Kim et al., 2008). The discrepancy can be attributed to the supply, in the present experiments, of newly formed "light" $\mathrm{NH}_{4}^{+}$by the ammonification of organic $\mathrm{N}$, which has a low value ( $\alpha=\sim 1000)$ of isotopic fractionation (Högberg, 1997). The weight decrease in the piles with bulking agent $(4543 \pm 137-1413 \pm 99 \mathrm{~kg})$ was greater than that in the piles without bulking agent $(4136 \pm 124-1960 \pm 291 \mathrm{~kg})$, indicating that a relatively large amount of "light" $\mathrm{NH}_{4}^{+}$was supplied to the piles with bulking agent. The $\delta^{15} \mathrm{~N}$ value of $\mathrm{NH}_{4}^{+}$ at the end of the experiments was significantly higher in the piles with bulking agent $(17.7 \pm 1.3 \%$ o) than in those without bulking agent (11.8 $\pm 0.9 \%$ ) (Fig. 2), indicating that the nitrogen transformation rate after the supply of newly formed ammonium was much higher in the piles with bulking agent.

In a previous work, we demonstrated that the use of bulking agent clearly reduced the greenhouse gas $\mathrm{N}_{2} \mathrm{O}$ emission (up to $62.8 \%$ ) when using the exact same scale and methods of dairy manure composting as used in the present study (Maeda et al., 2013a). Runs 2 and 3 in the previous work were identical to runs 1 and 2 in this study. However, the present study did not provide a detailed explanation for this result. Our initial hypothesis - that the use of bulking agent reduced nitrogen transformation by nitrificationdenitrification process, leading to lower $\mathrm{N}_{2} \mathrm{O}$ emission - was not supported by the present data. One possible explanation for the difference in the mitigation of $\mathrm{N}_{2} \mathrm{O}$ emission is the difference of temperature between the treatments, since it is known that the optimum temperature for the nitrifiers in the manure is around $35-40^{\circ} \mathrm{C}$, and much lower nitrification activity can be observed above $50^{\circ} \mathrm{C}$ (Willers et al., 1998). The optimum temperature for denitrification and $\mathrm{N}_{2} \mathrm{O}$ production can be higher than these values (Benoit et al., 2015), but denitrification requires the presence of $\mathrm{NO}_{2}^{-}$or $\mathrm{NO}_{3}^{-}$for electron acceptors. The use of a bulking agent enabled oxygen supply into the pile, which could have enhanced the oxidation of ammonium (nitrification), but the high temperature inside the piles $\left(>60^{\circ} \mathrm{C}\right)$ inhibited nitrification activity. Piles without a bulking agent showed lower temperature $\left(30-40^{\circ} \mathrm{C}\right)$, which could have enhanced the nitrification, denitrification and $\mathrm{N}_{2} \mathrm{O}$ emission in the piles without bulking agent. However, the higher nitrogen transformation achieved by other nitrogen transformations, such as $\mathrm{NH}_{3}$ volatilization, assimilation and re-degradation of the bacterial cells, could have contributed to the higher $\delta^{15} \mathrm{~N}$ value of $\mathrm{NH}_{4}^{+}$observed in the piles with bulking agent.

Because significantly different concentrations for not only $\mathrm{NH}_{4}^{+}$but also $\mathrm{NO}_{2}^{-}$and $\mathrm{NO}_{3}^{-}$were observed every 2 weeks (Fig. 1), it was suggested that the reactions proceeded in a different manner in each of the pile regions studied. To examine this possibility, we collected samples from each location (pile top, side and core) and confirmed that the $\mathrm{NH}_{4}^{+}$concentration was clearly higher in the top region of the samples just before the first turning event than in the more homogenous samples after the last turning event (Fig. 1). This result might be attributable to the high temperature of pile core, especially in the piles with bulking agent $\left(>60^{\circ} \mathrm{C}\right)$. The high temperature causes an internal convective airflow even if the piles are not aerated (Barrington et al., 2003; Lynch and Cherry, 1996; Yu et al., 2005), and this air flow can cause the transportation of $\mathrm{NH}_{3}-\mathrm{N}$ from the specific zone where significant ammonification of organic $\mathrm{N}$ occurs. $\delta{ }^{15} \mathrm{NH}_{4}^{+}$levels were also determined for these samples, and we found that the ${ }^{15} \mathrm{~N}$ value of $\mathrm{NH}_{4}^{+}$was significantly enriched in the top pile samples (Fig. 3). This finding indicated that the reaction rate was very high in the top pile zone, where significantly high $\mathrm{NH}_{4}^{+}$ and $\mathrm{NO}_{2}^{-}$concentrations were observed. The high $\mathrm{NH}_{4}^{+}$concentrations in the pile top could only be explained by the transport from the pile core, as stated above, but the $\mathrm{NH}_{4}^{+}$ in the pile core generally showed depleted $\delta^{15} \mathrm{NH}_{4}^{+}$(Fig. 3). We therefore performed a Keeling plot analysis to explain the phenomenon (Fig. 4a). If there were a single "heavy" ${ }^{15} \mathrm{NH}_{4}^{+}$source, we would expect to see a significant regression line between the ${ }^{15} \mathrm{NH}_{4}^{+}$values and inverse ammonium concentration. However, we did not see such a line, indicating that the nitrogen transformation and isotope fractionation occurred independently in each location. In turn, this means that the nitrogen transformation rate was extremely high in the pile top samples, which showed high $\mathrm{NH}_{4}^{+}$concentration with highly enriched $\delta^{15} \mathrm{~N}$ values. We can think of two possible explanations for the highly enriched $\delta^{15} \mathrm{NH}_{4}^{+}$. One is that the enrichment was due to extremely high nitrificationdenitrification activity in these samples, and the other is that it was due to high loss of nitrogen in the gaseous $\mathrm{NH}_{3}$ state.

Previously Casciotti et al. (2003) reported that biological ammonium oxidation by beta-proteobacterial ammonium oxidizing bacteria (AOB; four Nitrosomonas and one $\mathrm{Ni}$ trosospira species) has an isotopic effect that ranges from 14.2-38.2\%o. Another family of ammonium oxidizers, ammonium oxidizing archaea (AOA), also show isotopic fractionation during their activity, and this fractionation ranges from 13-41\%o (Santoro and Casciotti, 2011). Because the $\mathrm{pH}$ and availability of ammonia is one of the critical drivers partitioning these two ammonium oxidizers (Hatzenpichler, 2012), and manure compost shows high $\mathrm{pH}$ values and contains very high $\mathrm{NH}_{4}^{+}$concentration in general, $\mathrm{AOB}$, rather than AOA, seems to be the main oxidizer in the compost (Yamamoto et al., 2012). Because significant amounts of the bac- 

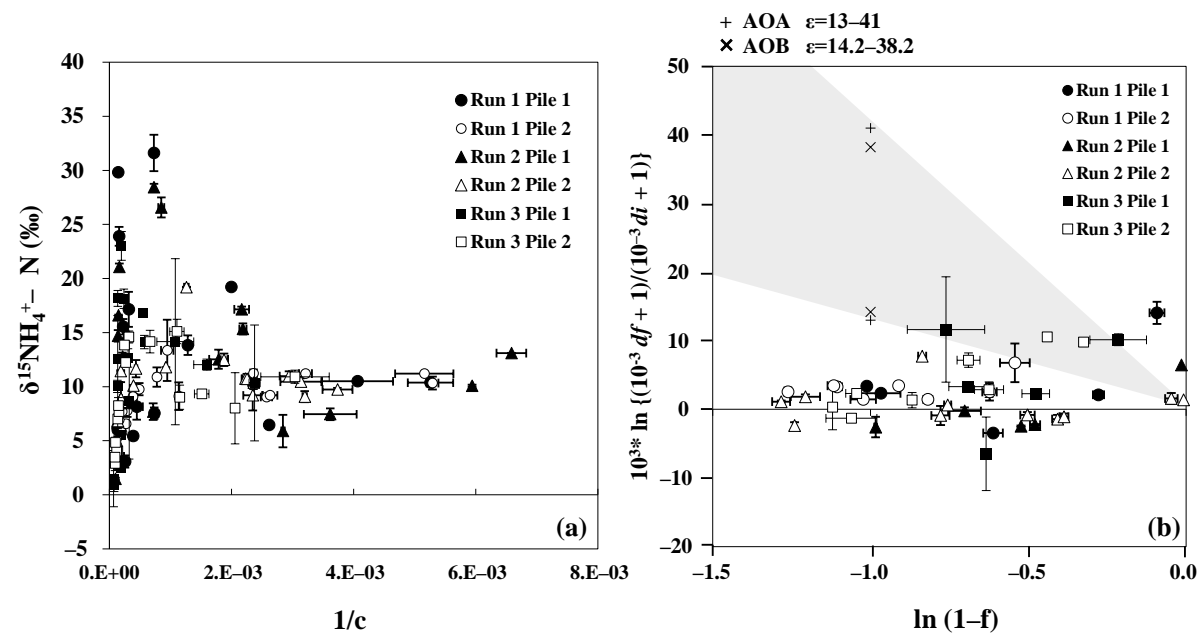

Figure 4. Keeling plot (a) and Rayleigh plot (b) of the $\delta^{15} \mathrm{NH}_{4}^{+}-\mathrm{N}$. The error bars indicate the standard deviation $(n=2)$. Black symbols indicate the compost with bulking agent $(10 \% \mathrm{w} / \mathrm{w})$ and white symbols indicate the compost without bulking agents. The gray zone indicate the area which can be explained by ammonium oxidation by AOB (ammonia oxidizing bacteria; 14.2-38.2\%o) or AOA (ammonium oxidizing archaea; $13-41 \%$ ).

terial $a m o A$ gene, which is required for ammonium oxidation by AOB, have been detected in both the pile top and side, but not in the pile core (Maeda et al., 2010b), the contribution of this gene is a possible explanation for the "heavy" ${ }^{15} \mathrm{NH}_{4}^{+}$, especially in pile top samples. Therefore we performed a Rayleigh plot analysis on our ${ }^{15} \mathrm{NH}_{4}^{+}$data and tried to explain these enriched values with nitrification by the microbes (Fig. 4b). However, only some plots were included in the area attributable to nitrification, and thus nitrification alone could not be the driving factor for these "heavy" ${ }^{15} \mathrm{NH}_{4}^{+}-\mathrm{N}$.

The isotope fractionation for $\mathrm{NH} 3$ volatilization and nitrification are similar, 1.029 and 1.015-1.035 (Högberg, 1997), In addition, it has been clearly established that high $\mathrm{NH}_{3}$ volatilization contributes to the enriched $\delta^{15} \mathrm{NH}_{4}^{+}$during cattle manure storage (Lee et al., 2011). Another study reported that $\mathrm{NH}_{4}^{+}$can easily exist in a gaseous state at high $\mathrm{pH}$ environment, and the temperature can also influence the fractionation ( $\mathrm{Li}$ et al., 2012). The $\delta^{15} \mathrm{~N}$ values of volatilized $\mathrm{NH}_{3}$ from compost piles on the same scale were very low ( -17.9 to $-13.5 \%$, unpublished data), and thus it would seem that $\mathrm{NH}_{3}$ volatilization would likely have contributed to these "heavy" $\mathrm{NH}_{4}^{+}$in the pile top, at least in part.

On the other hand, the significant increase in $\delta^{15} \mathrm{NH}_{4}^{+}$ in the latter stage of the process cannot be explained by $\mathrm{NH}_{3}$ volatilization, because most of this occurs during their initial stage of the process, as we showed previously (Maeda et al., 2013a). Although the relative contributions of $\mathrm{NH}_{3}$ volatilization and nitrification-denitrification to these $\delta^{15} \mathrm{NH}_{4}^{+}$increases are not clear, it is well known that nitrification occurs mainly during the latter stage of the process (Sanchez-Monedero et al., 2001), and the nitrification seems to contribute this increase significantly. Interestingly, highly enriched $\delta^{15} \mathrm{NH}_{4}^{+}$could be observed from the pile core zone

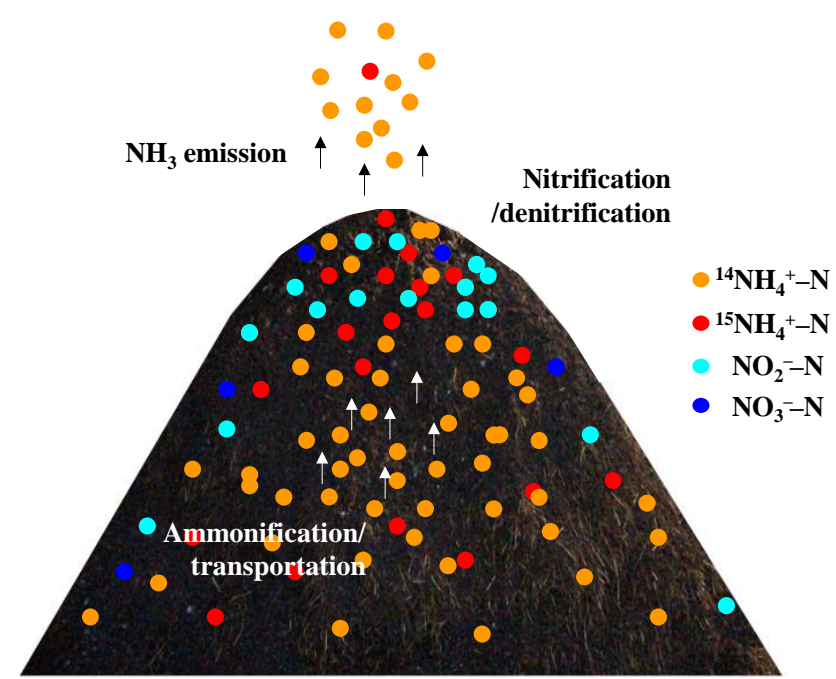

Figure 5. Summary of the events between the pile turnings.

at the end of the experiment in runs 1 and 2. This phenomenon cannot be explained by $\mathrm{NH}_{3}$ volatilization because of its location in the piles, and thus it could be achieved solely by the nitrification-denitrification process. It is well known that high nitrification can occur in the latter stage of the composting process (Bernal et al., 2009; Parkinson et al., 2004), and the $a m o A$ gene could be detected from the compost core even in the latter stage of the composting process; therefore, high nitrogen conversion by microbes seems likely to have occurred in the compost core, and this could contribute to the sharp increase of the $\delta^{15} \mathrm{NH}_{4}^{+}$of the mixed samples. 


\section{Conclusions}

The $\delta^{15} \mathrm{NH}_{4}^{+}$measurement of the samples collected from each location of the pile suggested an explanation for what occurred between the turnings. A plausible sequence of events between the pile turnings (Fig. 5) is as follows:

i. Ammonification of organic $\mathrm{N}$ supplies a large amount of "light" ammonium in the compost core, where high organic matter degradation activity can be achieved.

ii. This "light" ammonium is transported to the pile top zone by the upstream airflow generated by heat in the compost core zone.

iii. Significant nitrification, denitrification and $\mathrm{NH}_{3}$ volatilization occur in the pile top zone, leading to highly enriched $\delta^{15} \mathrm{NH}_{4}^{+}$in this zone, but these phenomena probably do not occur at significant levels in the pile side zone.

iv. The nitrification rate exceeds the denitrification rate, leading to accumulation of $\mathrm{NO}_{2}^{-}$in the pile top and side, which in turn contributes to significant denitrification and $\mathrm{N}_{2} \mathrm{O}$ emission just after the turning events.

On the other hand, the $\delta^{15} \mathrm{NH}_{4}^{+}$measurement of piles with and without bulking agent did not explain why $\mathrm{N}_{2} \mathrm{O}$ emission could be mitigated by the use of bulking agent, and thus further studies are needed.

\section{The Supplement related to this article is available online at doi:10.5194/bg-13-1341-2016-supplement.}

Author contributions. K. Maeda and S. Toyoda designed the experiments. K. Maeda, M. Yano and M. Fukasawa carried out the experiments. K. Maeda, S. Toyoda and S. Hattori analyzed the results. K. Maeda, K. Nakajima and N. Yoshida wrote the paper.

Acknowledgements. We would like to thank Atsuko Kobayashi and Kazuha Azumaya for providing the laboratory-based technical assistance. This work was supported by a grant for the "Development of Mitigation and Adaptation Techniques to Global Warming in the Sectors of Agriculture, Forestry, and Fisheries" from the Ministry of Agriculture, Forestry and Fisheries (MAFF), Japan. This work was also supported by a Grant-in-Aid for Young Scientists (B) to K. Maeda and a grant from the Global Environment Research Fund (B-094) of the Ministry of the Environment, Japan to N. Yoshida.

Edited by: X. Wang

\section{References}

Barrington, S., Choinière, D., Trigui, M., and Knight, W.: Compost convective airflow under passive aeration, Bioresource Technol., 86, 259-266, 2003.

Benoit, M., Garnier, J., and Billen, G.: Temperature dependence of nitrous oxide production of a luvisolic soil in batch experiments, Proc. Biochem., 50, 79-85, 2015.

Bernal, M., Alburquerque, J., and Moral, R.: Composting of animal manures and chemical criteria for compost maturity assessment: A review, Bioresource Technol., 100, 5444-5453, 2009.

Brooks, P., Stark, J. M., McInteer, B., and Preston, T.: Diffusion method to prepare soil extracts for automated nitrogen-15 analysis, Soil Sci. Soc. Am. J., 53, 1707-1711, 1989.

Casciotti, K., Sigman, D., and Ward, B.: Linking diversity and stable isotope fractionation in ammonia-oxidizing bacteria, Geomicrobiol. J., 20, 335-353, 2003.

Dämmgen, U. and Hutchings, N. J.: Emissions of gaseous nitrogen species from manure management: a new approach, Environ. Pollut., 154, 488-497, 2008.

Galloway, J. N., Dentener, F. J., Capone, D. G., Boyer, E. W., Howarth, R. W., Seitzinger, S. P., Asner, G. P., Cleveland, C. C., Green, P. A., and Holland, E. A.: Nitrogen cycles: past, present, and future, Biogeochemistry, 70, 153-226, 2004.

Garten Jr., C. T.: Nitrogen isotope composition of ammonium and nitrate in bulk precipitation and forest throughfall, Int. J. Environ. An. Ch., 47, 33-45, 1992.

Gruber, N. and Galloway, J. N.: An Earth-system perspective of the global nitrogen cycle, Nature, 451, 293-296, 2008.

Hatzenpichler, R.: Diversity, physiology, and niche differentiation of ammonia-oxidizing archaea, Appl. Environ. Microb., 78, 7501-7510, 2012.

Holmes, R. M., McClelland, J. W., Sigman, D. M., Fry, B., and Peterson, B. J.: Measuring ${ }^{15} \mathrm{~N}-\mathrm{NH}_{4}^{+}$in marine, estuarine and fresh waters: an adaptation of the ammonia diffusion method for samples with low ammonium concentrations, Mar. Chem., 60, 235-243, 1998.

Högberg, P.: ${ }^{15} \mathrm{~N}$ natural abundance in soil-plant systems, New Phytol., 137, 179-203, 1997.

IPCC: Synthesis Report, Contribution of Working Groups I. in: II and III to the Fourth Assessment Report of the Intergovernmental Panel on Climate Change, Core Writing Team, edited by: Pachauri and Reisinger, IPCC, Geneva, Switzerland, 2007.

Jolanun, B. and Towprayoon, S.: Novel bulking agent from clay residue for food waste composting, Bioresource Technol., 101, 4484-4490, 2010.

Kim, Y.-J., Choi, W.-J., Lim, S.-S., Kwak, J.-H., Chang, S. X., Kim, H.-Y., Yoon, K.-S., and Ro, H.-M.: Changes in nitrogen isotopic compositions during composting of cattle feedlot manure: effects of bedding material type, Bioresource Technol., 99, 5452-5458, 2008.

Lee, C., Hristov, A. N., Cassidy, T., and Heyler, K.: Nitrogen isotope fractionation and origin of ammonia nitrogen volatilized from cattle manure in simulated storage, Atmosphere, 2, 256270, 2011.

Li, L., Lollar, B. S., Li, H., Wortmann, U. G., and LacrampeCouloume, G.: Ammonium stability and nitrogen isotope fractionations for $-\mathrm{NH}_{3}$ (aq) $-\mathrm{NH}_{3}$ (gas) systems at $20-70^{\circ} \mathrm{C}$ and $\mathrm{pH}$ of 2-13: Applications to habitability and nitrogen cycling in 
low-temperature hydrothermal systems, Geochim. Cosmochim. Ac., 84, 280-296, 2012.

Lynch, N. J. and Cherry, R. S.: Design of passively aerated compost piles: vertical air velocities between the pipes, Biotechnol. Progr., 12, 624-629, 1996.

Maeda, K., Hanajima, D., Morioka, R., and Osada, T.: Characterization and spatial distribution of bacterial communities within passively aerated cattle manure composting piles, Bioresource Technol., 101, 9631-9637, 2010a.

Maeda, K., Toyoda, S., Shimojima, R., Osada, T., Hanajima, D., Morioka, R., and Yoshida, N.: Source of nitrous oxide emissions during the cow manure composting process as revealed by isotopomer analysis of and amoA abundance in betaproteobacterial ammonia-oxidizing bacteria, Appl. Environ. Microb., 76, 1555$1562,2010 b$.

Maeda, K., Hanajima, D., Morioka, R., Toyoda, S., Yoshida, N., and Osada, T.: Mitigation of greenhouse gas emission from the cattle manure composting process by use of a bulking agent, Soil Sci. Plant Nutr., 59, 96-106, 2013a.

Maeda, K., Toyoda, S., Hanajima, D., and Yoshida, N.: Denitrifiers in the surface zone are primarily responsible for the nitrous oxide emission of dairy manure compost, J. Hazard. Mater., 248-249, 329-336, 2013b.

Parkinson, R., Gibbs, P., Burchett, S., and Misselbrook, T.: Effect of turning regime and seasonal weather conditions on nitrogen and phosphorus losses during aerobic composting of cattle manure, Bioresource Technol., 91, 171-178, 2004.

Ravishankara, A., Daniel, J., and Portmann, R.: Nitrous oxide $\left(\mathrm{N}_{2} \mathrm{O}\right)$ : the dominant ozone-depleting substance emitted in the 21st century, Science, 326, 123-125, 2009.

Sanchez-Monedero, M. A., Roig, A., Paredes, C., and Bernal, M. P.: Nitrogen transformation during organic waste composting by the Rutgers system and its effects on $\mathrm{pH}, \mathrm{EC}$ and maturity of the composting mixtures, Bioresource Technol., 78, 301-308, 2001.

Santoro, A. E. and Casciotti, K. L.: Enrichment and characterization of ammonia-oxidizing archaea from the open ocean: phylogeny, physiology and stable isotope fractionation, ISME J., 5, 17961808,2011
SAS Institute: I. SAS/STAT user's guide, SAS Institute, Cary, NC, 2001.

Sharpley, A., Meisinger, J. J., Breeuwsma, A., Sims, J. T., Daniel, T. C., and Schepers, J. S.: Impacts of Animal Manure Management on Ground and Surface Water Quality. Animal Waste Utilization: Effective Use of Manure as a Soil Resource, edited by: Hatfield, J. L., and Stewart, B. A., CRC Press, Boca Raton, FL, 173-242, 1998.

Sommer, S., Olesen, J., Petersen, S., Weisbjerg, M., Valli, L., Rodhe, L., and Beline, F.: Region specific assessment of greenhouse gas mitigation with different manure management strategies in four agroecological zones, Glob. Change Biol., 15, 2825 2837, 2009.

Tilman, D., Cassman, K. G., Matson, P. A., Naylor, R., and Polasky, S.: Agricultural sustainability and intensive production practices, Nature, 418, 671-677, 2002.

Willers, H. C., Derikx, P. J. L., ten Have, P. J. W., and Vijn, T. K.: Nitrification limitation in animal slurries at high temperatures, Bioresour. Technol., 64, 47-54, 1998.

Yamamoto, N., Oishi, R., Suyama, Y., Tada, C., and Nakai, Y.: Ammonia-oxidizing bacteria rather than ammonia-oxidizing archaea were widely distributed in animal manure composts from field-scale facilities, Microbes Environ., 27, 519-524, 2012.

Yeatman, S., Spokes, L., Dennis, P., and Jickells, T.: Can the study of nitrogen isotopic composition in size-segregated aerosol nitrate and ammonium be used to investigate atmospheric processing mechanisms?, Atmos. Environ., 35, 1337-1345, 2001.

Yu, S., Clark, O., and Leonard, J.: Airflow measurement in passively aerated compost, Canad. Biosyst. Eng., 47, 39-45, 2005.

Zumft, W. G.: Cell biology and molecular basis of denitrification, Microbiol. Mol. Biol. Rev., 61, 533-616, 1997. 